\title{
SINDROMUL STEVENS-JOHNSON (SSJ) ȘI NECROLIZA TOXICĂ EPIDERMALĂ DE ETIOLOGIE MEDICAMENTOASĂ
}

\author{
Dalia Dop, Desdemona Stepan, Cristian Gheonea, Elena Carmen Niculescu \\ Clinica I Pediatrie, Universitatea de Medicină şi Farmacie, Craiova
}

\begin{abstract}
REZUMAT
Sindromul Stevens-Johnson (SSJ) şi necroliza toxică epidermală (NTE) sunt afecțiuni rare care apar după administrarea medicamentelor cu risc. Ambele reprezintă grade de severitate ale aceleiaşi afecțiuni şi sunt considerate urgențe medicale, deoarece sunt potențial letale. Sunt caracterizate prin sensibilitate cutaneomucoasă, eritem, necroză şi dezlipire buloasă similar arsurilor extinse. În continuare vă prezentăm 3 cazuri de SSJ/NTE a căror etiologie a fost, probabil, medicamentoasă (Paracetamol, Atomoxetinum, Sulfamethoxazolum + trimethoprinum), cu refacere totală după administrarea de imunoglobuline intravenos.
\end{abstract}

Cuvinte cheie: sindromul Stevens-Johnson, necroliza toxică epidermală, etiologie medicamentoasă, imunoglobuline intravenos

Sindromul Stevens-Johnson (SSJ) şi necroliza toxică epidermală (NTE) reprezintă variante de severitate ale unei boli multi-organice rare, mediată imun, care afectează în special tegumentele şi mucoasele. Etiologia medicamentoasă reprezintă principala cauză a acestor afecțiuni, dar pot fi implicate şi Mycoplasma pneumoniae şi infecțiile virale cu Herpes simplex. În unele cazuri, etiologia rămâne necunoscută (1). Din cauza riscului ridicat de mortalitate, pacienții cu SJS necesită diagnostic rapid, identificarea şi întreruperea medicamentului vinovat şi tratament specializat de îngrijire într-o unitate de terapie intensivă (2). Vă supunem atenției 3 cazuri de SSJ diagnosticate în Clinica I Pediatrie a Spitalului Clinic Județean de Urgență, Craiova în perioada 01.01.2009-30.03.2016 pe baza criteriilor anamnestice, clinice şi paraclinice.

\section{PREZENTARE DE CAZ}

\section{Cazul nr. 1}

Prezentăm cazul unui pacient de sex F, în vârstă de 1 an şi 5 luni, din mediu rural, care se internează prin transfer de la Spitalul Caracal pentru stare generală alterată, erupție eritemato-papuloasă generalizată, edeme palpebrale şi ale feței, tuse. Antecedentele heredo-colaterale sunt nesemnificative.
Antecedentele personale fiziologice au relevat că este primul copil din sarcină urmărită, iminență de avort la 3 luni, tratament pe timpul sarcinii pe care nu îl poate preciza, naştere la termen, pe cale naturală, prezentație craniană, având greutatea la naştere $3.200 \mathrm{~g}$, alimentat natural 4 luni, ulterior lapte de vacă, diversificat incorect la 41 , vaccinări efectuate. Antecedentele personale patologice au evidenţiat la 1 an şi 3 luni - strepto-stafilococie cutanată tratată cu topice cutanate.

Debutul bolii actuale a fost cu 7 zile anterior internării, cu simptome respiratorii, pentru care primeşte tratament cu Albuterol, Fluticasonum propionat inhalator, Paracetamol. La scurt timp apar macule eritematoase diseminate pe față şi membrele inferioare, interpretate drept alergodermie. Se internează inițial la Spitalul Caracal unde urmează tratament cu Ceftriaxon, Gentamicină, Hydrocortisone Hemisuccinate, Albuterol şi Fluticasonum propionate inhalator timp de 3 zile, cu evoluție favorabilă a simptomelor respiratorii, dar cu accentuarea şi generalizarea erupției cutanate.

Examenul obiectiv la internare a pus în evidență următoarele elemente patologice: stare generală alterată, eritem cu edem al feței, cu zone violacee şi flictene la nivel mentonier, în regiunea deltoidiană şi a brațelor, erupție eritemato-papuloasă şi peteşia- 
lă generalizată cu extensie rapidă în decurs de câteva ore, buze uscate, fisurate, săngerâri locale şi cruste hematice, edem palpebral bilateral, secreție conjunctivală seroasă minimă, stetacustic pulmonar raluri ronflante bilateral, sindrom meningean absent.

Analizele de laborator efectuate în momentul internării evidențiază: anemie hipocromă microcitară (Hb 10,1 g/dl, VEM 78,3 fL, HEM 26,9 pg/dl), transaminaze crescute (GOT 70 UI, GPT 62 UI), hiponatremie ( $\mathrm{Na} 134,2 \mathrm{mmol} / \mathrm{L})$, hipopotasemie (K 2,9 $\mathrm{mmol} / \mathrm{L}$ ) şi $\mathrm{VSH}=20 / 42 \mathrm{~mm}$. Hemocultura a fost negativă, imunograma normală, iar radiografia cardio-pulmonară fără modificări. Examenul oftalmologic a evidențiat pol anterior normal, reflexe pupilare prezente bilateral, iar la fundul de ochi se întrezăresc papile bine conturate. Examenul dermatologic ridică suspiciunea de sindrom Stevens-Johnson. Anticorpi IgM virusul herpex simplex (HSV1, HSV2) negativi, anticorpi anti virusul imunodeficienței umane HIV 1, 2 negativi, Anticorpi IgM şi IgA pentru Mycoplasma pneumoniae - negativi.

S-a instituit tratament de reechilibrare hidroelectrolitică, Aminoven 10\%, Smof lipid 3 zile, ulterior alimentație orală, antibiotic (Meropenem), corticosteroizi sistemici, antihistaminice, antitermice, tratament local dermatologic şi oftalmologic, tratament chirurgical local.

Evoluția leziunilor cutanate a fost inițial de generalizare a exantemului cu elemente veziculo-buloase cu tendința la confluare, bule decapate la nivel bucal, nazal, genital. Ulterior evolutia a fost lent favorabilă, cu descuamări tegumentare în lambouri care au lăsat zone eritematoase curate, dar la 10 zile de la internare reapare sindromul febril, cu 3-4 pusee febrile/zi, este polipneică în perioada febrilă, stetacustic pulmonar fără modificări, echilibrată cardio-circulator, primeşte alimentația oral, se joacă cu mama, fiind agitată doar în momentul consultului. În acest moment se transferă pe secția ATI unde se administrează Imunoglobuline iv $2 \mathrm{~g} / \mathrm{kg}$, timp de 5 zile, cu evoluție favorabilă, fiind externată la 2 săptămâni cu restituțio ad integrum.

Particularitatea cazului constă în apariţia sindromului Stevens-Johnson la o pacientă cu infecție de căi respiratorii inferioare şi tratament cu antiinflamatorii nesteroidiene (Paracetamol) cu evoluție prelungită, dar cu restituțio ad integrum după administrarea de imunoglobuline i.v.

\section{Cazul nr. 2}

Prezentăm cazul unui copil în vârsta de 7 ani, de sex masculin, care se internează pentru febră, stare generală alterată, erupție maculo-veziculoasă generalizată, edem al buzelor, afte bucale, secreții conjunctivale. Din antecedentele heredo-colaterale am reținut că bunicul şi mătuşa maternă sunt diagnosticaţi cu epilepsie. Antecedentele personale fiziologice sunt nesemnificative. Din antecedentele personale patologice reținem că la vârsta de 1 an şi 6 luni este diagnosticat cu epilepsie reflexă (crize parțial complexe declanşate la baie) pentru care urmează iniţial tratament cu Acid valproic, la care se adaugă în urmă cu patru săptămâni anterior internării Atomoxetin. Menționăm, de asemenea, că la vârsta de 3 ani este diagnosticat $\mathrm{cu}$ sindrom hiperkinetic şi enurezis pentru care nu urmează tratament.

Debutul bolii actuale a fost cu $24 \mathrm{~h}$ anterior internării prin edem al buzelor pentru care primeşte tratament cu antihistaminice, calciu. După câteva ore apare hiperemie conjunctivală, erupție eritemato-veziculară pe membre, ulterior şi la nivelul regiunii cervicale; sialoree şi afte la nivelul cavității bucale. Se prezintă la Spitalul de Boli Infecțioase Craiova unde se ridică suspiciunea de sindrom Stevens-Johnson şi este redirecționat către Spitalul Clinic Județean de Urgentă Craiova.

Examenul obiectiv la internare a pus în evidență următoarele elemente patologice: stare generală alterată, edem al buzelor, afte la nivelul cavității bucale, sialoree, hiperemie conjunctivală, secreții purulente la ambii ochii, erupție eritemato-veziculoasă la nivelul feței, regiunii cervicale, membre, eroziuni la nivelul maleolei stângi, sindrom meningean absent.

Analizele de laborator efectuate în momentul internării evidențiază leucocitoză (L 18.200/ mmmc) cu neutrofilie (N 79\%) şi reactanți de fază acută negativi. Urocultura şi hemocultura au fost negative. Examenul oftalmologic a evidențiat secreție conjunctivală bilaterală, la ochiul drept cornea fixează colorantul la limb la ora 1-2, în rest pol anterior normal, iar la ochiul stâng cornea nu reține colorantul. Anticorpi IgM virusul herpex simplex (HSV1, HSV2) negativi, anticorpi anti virusul imunodeficienței umane HIV 1, 2 negativi, anticorpi IgM şi IgA pentru Mycoplasma pneumoniae - negativi. Examenul de chirurgie bucomaxilofacială a evidențiat stomatită ulcero-necrotică secundară bolii de bază.

S-a întrerupt administrarea de Atomoxetin şi s-a instituit tratament de susţinere volemică, Aminoven, antibiotic (Ampicilină), corticoizi sistemici, antihistaminice, antitermice, tratament local dermatologic şi oftalmologic şi s-a continuat administrarea de acid valproic. Inițial, erupția tegumentară eritemato-maculo-veziculoasă s-a generalizat, apar 
elemente buloase care confluează, se sparg lăsând eroziuni acoperite de cruste hematice, sângerânde la nivelul buzelor, mucoasei jugale, limbii, mucoasei genitale, edem al scrotului, ulterior apare descuamare tegumentară în lambouri sau fină şi ulterior reepitelizare treptată tegumentară şi a mucoaselor. Pacientul este externat în a 17 -a zi de la internare afebril, cu descuamare fină pe trunchi, fără cruste pe tegumente, cruste în curs de detaşare pe buze, echilibrat cardio-respirator, abdomen suplu, apetit prezent.

Particularitatea cazului constă în apariția sindromului Stevens-Johnson la câteva săptămâni de la începerea tratamentului cu Atomoxetin la un şcolar cu epilepsie, evoluția fiind favorabilă, fără apariția complicațiilor.

\section{Cazul nr. 3}

Prezentăm cazul unui copil în vârsta de 5 ani, de sex feminin, care se internează pentru edem al buzelor, placarde papulo-eritematoase la nivelul feței, palmelor şi plantelor, disurie, polakiurie. Antecedentele heredo-colaterale şi personale fiziologice sunt nesemnificative. Antecedentele personale patologice au evidențiat episoade recurente de infecții urinare (ITU), reflux vezico-ureteral.

Debutul bolii actuale a fost cu 10 zile anterior internării prin disurie, polakiurie; efectuează urocultura care este pozitivă pentru Escherichia Coli şi primeşte tratament cu Sultamicillină, 5 zile, ulterior Sulfamethoxazolum + trimethoprinum. $\mathrm{Cu}$ trei zile anterior internării, prezintă hiperemie conjunctivală pentru care a primit tratament local cu Azitromicină. Cu 12 h anterior internării, prezintă erupție maculo-eritematoasă la nivelul obrajilor, plantelor, palmelor şi ulterior la nivelul trunchiului, motiv pentru care se internează.

Examenul obiectiv la internare a pus în evidență următoarele elemente patologice: stare generală influențată, exces ponderal, edem al buzelor, edeme palpebrale, secreții conjunctivale la ambii ochii, erupție eritemato-maculoasă în placarde la nivelul feței, trunchiului şi membrelor, mai intensă la nivelul palmelor şi plantelor, leziuni veziculoase la nivelul gingiei şi buzelor, abdomen sensibil difuz, disurie, polakiurie, sindrom meningean absent. Analizele de laborator efectuate în momentul internării evidențiază leucocitoză (L 18.900) cu neutrofilie (N 77\%), reactanți de fază acută pozitivi (VSH 18/32 mm; fibrinogen $410 \mathrm{mg} / \mathrm{dl}$ ) şi glicemie 120 $\mathrm{mg} / \mathrm{dl}$. Probele hepatice au fost modificate (GOT 806 U1, GPT 864 UI) cu valori normale ale bilirubinemiei. A prezentat hipernatremie ( $\mathrm{Na} 153 \mathrm{mmol} / \mathrm{L}$ ) cu normopotasemie şi rezerva alcalină 18,6 mEq/l.
Urocultura a fost pozitivă pentru Escherichia Coli, iar examenul oftalmologic a evidenţiat conjunctivită acută bilaterală. Imunograma a fost negativă, de asemenea şi markeri hepatici pentru hepatita virală (Atg HBS, Anti HAV Ig M, antiHCV IgM). Anticorpi IgM virusul herpex simplex (HSV1, HSV2), anticorpi anti virusul imunodeficienței umane HIV 1, 2, precum şi anticorpi IgM şi IgA pentru Mycoplasma pneumoniae au fost negativi.

S-a întrerupt administrarea de Sulfamethoxazol+ trimethoprim şi s-a instituit tratament de reechilibrare hidro-electrolitică şi acidobazică, Aspatofort, antibiotic (Cefoperazonă + Sulbactam), corticoizi sistemici, antihistaminice, antitermice, tratament local dermatologic, oftalmologic şi al cavității bucale. Evoluția a fost nefavorabilă, cu generalizarea erupției tegumentare, cu leziuni buloase cu conținut serocitrin decapate la nivelul feței, plantelor şi palmelor, leziuni ulcerative acoperite de false membrane la nivelul cavității bucale, genitale, congestie şi secreții conjunctivale la ambii ochii, sialoree, deglutiție dificilă, disurie. Astfel, s-au introdus în tratament Imunoglobuline i.v. $2 \mathrm{~g} / \mathrm{kg}$, timp de 5 zile, ulterior evoluția fiind favorabilă.

Particularitatea cazului constă în apariția sindromului Stevens-Johnson, complicat cu hepatită reactivă la o pacientă de 5 ani cu infecție urinară, care urma tratament cu Sulfamethoxazol şi Trimethoprim.

\section{DISCUȚII}

NTE şi SJS afectează aproximativ 1 sau 2/1.000.000 anual şi sunt considerate urgențe medicale, deoarece sunt potențial letale (1). Amândouă reprezintă grade de severitate ale aceleiaşi afecțiuni. Astfel, afectarea sub 10\% din suprafața pielii, este denumit SSJ, afectarea între 10 şi $30 \%$ este denumit overloap; SSJ/NTE, iar afectarea a mai mult de 30\% reprezintă NTE (3). Cazul nr. 1 a prezentat o afectare de aproximativ $20 \%$ din suprafaţa pielii deci reprezintă un overlap, cazul nr. 2 a prezentat sub $10 \%$ din suprafaţa pielii deci reprezintă un sindrom Stevens-Jonhson, iar cazul numărul 3 a prezentat peste $30 \%$, reprezentând necroliza toxică epidermolitică.

Cauza principală a SSJ este reprezentată de administrarea medicamentelor cu risc, aici intrând alopurinolul, sulfonamidele, aminopenicilinele, macrolidele, chinolonele, tetraciclinele, cefalosporinele, carbamazepina, fenobarbitalul, fenitoina, antiinflamatoare nesteroidiene (AINS), corticosteroizi (2-7). Infecțiile cu Mycoplasma pneumonia sau infecțiile virale (herpex simplex sau HIV), radi- 
oterapia recentă, neoplasmele şi bolile de colagen sunt suspectate a avea un rol în inducerea SSJ (8).

Fiziopatologia SJS/RTE rămâne necunoscută, dar mecanismele imunologice, reacțiile citotoxice şi hipersensibilitatea întârziată par a fi implicate (9). Manifestările de debut sunt necaracteristice, ulterior apar elemente eritemato-maculoase pe trunchi şi la nivelul feței care se generalizează, apar necroza şi detaşarea buloasă a epidermului asemănător arsurilor întinse. Alături de epiderm sunt afectate şi mucoasele orală, genitală, anală, conjunctivală, digestivă, respiratorie (2).

Diagnosticul se bazează în principal pe semnele clinice, împreună cu analiza histologică a unei biopsii a pielii care arată necroliza tipică epidermică din cauza apoptozei extinse a cheratinocitelor.

Întreruperea medicației declanşatoare ar trebui să fie o prioritate atunci când se suspicionează SSJ. Garcia-Doval şi colaboratorii au arătat că întreruperea rapidă a medicamentului incriminat determină un prognostic mai bun, iar pacienții expuşi la medicamentele cauzatoare pe o perioadă mai mare au un risc crescut de a deceda $(1,12)$. Pentru identificarea medicamentului incriminat este important să se ia în considerare cronologia administrării medicamentului şi capacitatea raportată de inducere a SJS/NTE. Apariția SSJ secundară administrării unui tratament se produce la distanţă de 1 până la 8 săptămâni de la iniţierea tratamentului $(2,11)$. În cazurile prezentate, apariția primelor leziuni a fost la 1 săptămână de la inițierea terapiei în cazurile 1 şi 3 şi la 4 săptămâni la cazul numărul 2. În toate cele 3 cazuri, medicamentul suspect a fost întrerupt de îndată ce s-a ridicat suspiciunea de SSJ.

Sechelele sunt caracteristice în general NET şi sunt reprezentate de afectări cutanate hipo sau de- pigmentări, distrofii unghiale, complicații oculare, mai rar ale mucoasei ureterale sau digestive $(12,13)$. Mortalitatea este raportată a fi de $1-5 \%$ în cazul SSJ şi de $25-35 \%$ în cazul NTE $(1,14)$.

Tratamentul SJS/NTE este similar cu tratamentul arsurilor majore şi include tratamentul de susținere şi îngrijire a plăgilor, menţinerea volemiei, antibiotice cu spectrul larg, tratamentul cu medicamente imunosupresive. $\mathrm{Cu}$ toate că administrarea parenterală a corticosteroizilor şi imunoglobulinelor (IGIV) este utilizată pentru tratamentul SJS/ RTE, studiile sunt contradictorii $(9,15)$. În cazul nostru, corticosteroizi parenteral au fost administrați de la debut şi evoluția a fost favorabilă la cazul numărul 2. În celelalte două cazuri, complicate cu infecții, s-au utilizat imunoglobuline iv care au determinat evoluția favorabilă cu restitution ad integrum.

\section{CONCLUZII}

Sindromul Stevens-Johnson este o afecțiune rară care pune probleme de diagnostic diferențial în faza inițială a bolii. Diagnosticul iniţial în toate cele trei cazuri a fost de alergodermie, iar etiologia a fost probabil medicamentoasă (Paracetamol, Atomoxetin, Sulfamethoxazol + Trimethoprin) în 2 cazuri survenind pe fondul unor infecții (respiratorie, respectiv urinară). Evoluția a fost favorabilă la cazul nr. 2, fără complicații, în timp ce cazurile de sindrom Stevens-Johnson care au debutat pe fondul unor infecții s-au complicat, evoluția fiind prelungită (6-9 săptămâni), dar cu restituțio ad integrum după administrarea de imunoglobuline i.v. 